\title{
PENINGKATKAN KEMAMPUAN GURU MATEMATIKA DALAM MELAKSANAKAN PENELITIAN TINDAKAN KELAS MELALUI BIMBINGAN INDIVIDUAL DI SMP NEGERI 3 KOTA BIMA
}

\author{
Arnasari Merdekawati Hadii ${ }^{*}$, Saifullah ${ }^{1}$ \\ ${ }^{1}$ Program Studi Pendidikan Matematika, STKIP Bima \\ *Email korespondensi: arnasari.mh_mat@stkipbima.ac.id
}

\begin{abstract}
ABSTRAK
Sebagai upaya mengembangkan kompetensi guru sesuai kebutuhan berkelanjutan untuk meningkatkan profesi sesuai tugasnya maka guru pertama dengan pangkat Penata Muda sampai dengan guru utama dengan pangkat Pembina Utama wajib melakukan pengembangan keprofesian berkelanjutan yaitu 1) pengembangan diri, 2) publikasi ilmiah, 3) pengembangan karya inovatif, hal ini berdasarkan Peraturan Mentri Negara Reformasi Birokrasi No.16 tahun 2009. Kenyataan di lapangan menunjukkan bahwa masih banyak guru matematika di SMP Negeri 3 Kota Bima yang perlu dibina dalam hal tersebut. Sebagian guru masih ada yang belum memahami cara membuat proposal, melaksanakan dan melaporkan hasil penelitiannya dengan baik, dan sebagian lainnya adapula yang sudah memahami tetapi belum melaksanakannya. Hal ini cenderung disebabkan oleh perhatian guru untuk mengadakan penelitian dan menulis karya ilmiah masih sangat rendah. Penelitian ini bertujuan untuk meningkatkan kemampuan guru matematika SMP Negeri 3 Kota Bima dalam melaksanakan penelitian tindakan kelas melalui teknik bimbingan individual. Jenis penelitian yang digunakan adalah penelitian tindakan kelas (PTK) yang dilaksanakan di SMP Negeri 3 Kota Bima pada semester genap tahun pelajaran 2017/2018 mulai bulan Januari 2018 sampai dengan Maret 2018. Subyek penelitian adalah guru mata pelajaran matematika berjumlah lima orang. Instrumen yang digunakan dalam penelitian ini adalah lembar observasi guru dan lembar wawancara. Hasil penelitian menunjukkan bahwa terjadi peningkatan kemampuan guru dalam melaksanakan penelitian tindakan kelas. Hal tersebut terlihat dengan meningkatnya hasil kinerja guru dari siklus I sebesar 2,36 dengan kategori cukup baik menjadi 3,38 dengan kategori baik pada siklus II.
\end{abstract}

Kata Kunci : Penelitian Tindakan Kelas, Bimbingan Individual

\begin{abstract}
In an effort to develop teacher competencies according to ongoing needs to improve the profession according to their duties, the first teacher with the rank of Young Administrator up to the main teacher with the position of Main Trustee must carry out continuous professional development namely 1) self-development, 2) scientific publications, 3) development of innovative work, this is based on the Regulation of the Minister of State for Bureaucratic Reform 16 of 2009. The reality in the field shows that there are still many mathematics teachers in SMP Negeri 3 Kota Bima who need to be fostered in this matter. Some teachers still do not understand how to make proposals, carry out and report the results of their research well, and some others who have understood but have not implemented it. This tends to be due to the attention of teachers to conduct research and write scientific papers is still very low. This study aims to improve the ability of mathematics teachers at SMP Negeri
\end{abstract}


3 Kota Bima to carry out classroom action research through individual guidance techniques. The type of research used is class action research (PTK) which is carried out in the Middle School 3 of Bima City in the even semester of the 2017/2018 school year starting from January 2018 to March 2018. The research subjects were five mathematics teachers. The instruments used in this study were teacher observation sheets and interview sheets. The results showed that there was an increase in the ability of teachers to carry out classroom action research. This can be seen from the increase in teacher performance results from the first cycle of 2,36 with a fairly good category to 3,38 in the good category in the second cycle.

Keywords: Class Action Research, Individual Guidance

\section{PENDAHULUAN}

Dalam jenjang jabatan, pangkat golongan, ruang sebagai salah satu bentuk penghargaan terhadap kinerja guru adalah dengan persyaratan angka kredit kumulatif minimal. Berdasarkan Peraturan Mentri Negara Reformasi Birokrasi No.16 tahun 2009, guru pertama dengan pangkat Penata Muda sampai dengan guru utama dengan pangkat Pembina Utama wajib melakukan pengembangan keprofesian berkelanjutan yaitu 1) pengembangan diri, 2) publikasi ilmiah, 3) pengembangan karya inovatif. Hal ini bertujuan untuk mengembangkan kompetensi guru sesuai kebutuhan berkelanjutan untuk meningkatkan profesi sesuai tugasnya. Kegiatan pengembangan diri dalam rangka meningkatkan kompetensi guru dan atau pemanfaatan wawasan pengetahuan, sikap, nilai ketrampilan sesuai dengan profesi guru yang bermanfaat dalam melaksanakan tugas serta meningkatkan keprofesian guru yang bersangkutan dalam kurun waktu tertentu telah banyak dan sering dilakukan dan diikuti guru.

Guru adalah pendidik profesional dengan tugas utama mendidik, mengajar, membimbing, mengarahkan, melatih, menilai dan mengevaluasi peserta didik pada pendidikan anak usia dini, pendidikan formal, pendidikan dasar dan menengah. Dengan mengemban kegiatan pembelajaran, melaksanakan pembelajaran yang bermutu, menilai dan mengevaluasi hasil pembelajaran, menyusun dan melaksanakan program perbaikan pengayaan terhadap peserta didik serta melaksanakan perbaikan tindak lanjut bimbingan dengan memanfaatkan hasil evaluasi. Namun pengembangan keprofesian berkelanjutan (PKB) dalam bentuk publikasi ilmiah/penelitian dan atau karya inovatif masih jarang dilakukan guru, terlebih guru matematika di SMP Negeri 3 Kota Bima. Dalam hal ini guru dituntut mampu menyusun proposal penelitian pendidikan, sekaligus merumuskan berbagai permasalahan dalam pembelajaran yang penting untuk diteliti. 
Kenyataan di lapangan menunjukkan bahwa guru matematika di SMP Negeri 3 Kota Bima belum mengurus kenaikan golongan karena tidak memiliki kemampuan membuat karya tulis ilmiah dalam hal ini menyusun dan melaksanakan penelitian tindakan kelas. Dari hasil wawancara, guru matematika belum memahami cara membuat proposal, melaksanakan dan melaporkan hasil penelitiannya dengan baik. Hal ini cenderung disebabkan oleh perhatian guru untuk mengadakan penelitian dan menulis karya ilmiah masih sangat rendah dan menganggap bahwa melaksanakan PTK adalah pekerjaan yang rumit. Strategi sosialisasi dan pelatihan PTK (penelitian tindakan kelas) selama ini ternyata masih belum memadai untuk menjangkau seluruh guru matematika dalam waktu relatif singkat. Intensitas dan kedalaman penguatan materi kurang dapat dicapai.

Berdasarkan kenyataan tersebut maka salah satu upaya yang dapat dilakukan sebagai upaya penguatan kompetensi guru matematika dalam penelitian tindakan kelas adalah melalui teknik bimbingan individual. Hal ini dimaksudkan untuk dapat memberikan pemahaman dan motivasi pada guru matematika Kota Bima dalam menyelesaikan permasalahan pembelajaran di sekolah melalui metode ilmiah. Penggunaan teknik bimbingan individual ini telah berhasil dilakukan oleh Aswati (2015) dlam penelitiannya menjelaskan bahwa bimbingan individual mampu meningkatkan kemampuan guru dalam melaksanakan penelitian tindakan kelas. Selain untuk menumbuhkan kretifitas dan motivasi untu lebih baik, melaksanakan penelitian tindakan kelas dapat digunakan untuk meningkatkan angka kredit sertifikasi yang pada akhirnya akan meningkatkan kesejahteraan guru itu sendiri. Penelitian ini bertujuan untuk meningkatkan kemampuan guru matematika SMP Negeri 3 Kota Bima dalam melaksanakan penelitian tindakan kelas melalui teknik bimbingan individual.

\section{METODE PENELITIAN}

Jenis penelitian yang digunakan adalah penelitian tindakan kelas (PTK). Jatmiko (2014:2) menyatakan bahwa PTK adalah suatu bentuk penelitian yang bersifat reflektif dengan melakukan tindakan-tindakan tertentu agar dapat memperbaiki dan/atau meningkatkan praktek-praktek pembelajaran di kelas secara lebih profesional. Tujuan dari penelitian ini adalah untuk meningkatkan kemampuan guru matematika SMP Negeri 3 Kota Bima dalam melaksanakan penelitian tindakan kelas melalui teknik bimbingan individual. Penelitian ini dilaksanakan di SMP Negeri 3 Kota Bima pada semester genap tahun pelajaran 2017/2018 
mulai bulan Januari 2018 sampai dengan Maret 2018. Subyek penelitian adalah guru mata pelajaran matematika berjumlah lima orang.

Dalam penelitian tindakan sekolah ini terdiri dari empat komponen pokok yaitu: perencanaan, tindakan, pengamatan, dan refleksi. Terdapat dua siklus yang dirancang dalam penelitian tindakan sekolah ini, yaitu siklus I dan siklus II. Alasan penelitian ini dibagi menjadi dua siklus adalah untuk menyesuaikan materi dan agar hasil peningkatan kemampuan guru Imatematika dalam melaksanakan PTK di setiap siklus terlihat.

Instrumen yang digunakan dalam penelitian ini adalah lembar observasi kinerja guru dan lembar wawancara tak terstruktur. Lembar observasi digunakan untuk melihat aktivitas yang dilakukan guru selama membuat proposal dan melaksanakan PTK di kelas, sedangkan lembar wawancara digunakan untuk mendalami pengetahuan awal guru mengenai PTK dan untuk mencari hambatan apa yang dihadapi dalam melaksanakan PTK di kelas.

Guru dikatakan berhasil dalam melaksanakan PTK jika skor rata-rata yang diperoleh 3,35 $\leq \mathrm{X}<4.05$ dan dikatakan belum berhasil jika persentase yang diperoleh $\mathrm{X}<3.35$. Skala yang digunakan dalam penelitian ini disusun berdasarkan skala likert dengan 5 pilihan jawaban. Untuk skala kinerja guru dalam melaksanakan PTK pilihan jawabannya adalah Sangat Baik (SB), Baik (BK), Cukup Baik (CB), Kurang Baik (KB) dan Sangat Kurang Baik (SKB). Semua skala disusun berdasarkan item positif yang penilaian atas itemnya sebagai berikut:

Tabel 1. Skala Pengukuran

\begin{tabular}{ccc}
\hline Ket & Kriteria & Item \\
\cline { 2 - 3 } SB & Sangat Baik & Positif \\
BK & Baik & 4 \\
CK & Cukup Baik & 3 \\
KB & Kurang Baik & 2 \\
SKB & Sangat Kurang Baik & 1 \\
\hline
\end{tabular}

Data yang akan diambil dalam penelitian ini adalah data dari skala penelitian yang diisi oleh peneliti sebagai observer selama guru membuat proposal dan membuat laporan hasil PTK. 
Data yang diperoleh dalam penelitian ini akan dianalisis dengan menghitung nilai ratarata kinerja guru selama penelitian untuk setiap kali pertemuan. Setelah dilakukan bimbingan individual dalam melaksanakan penelitian tindakan kelas, berikut adalah hasil penelitian pada siklus I dan siklus II.

Tabel 2. Hasil Observasi Kinerja Guru Siklus I

\begin{tabular}{ccccc}
\hline Nama Sekolah & Nama Guru & Skor total & Skor rata-rata & Kategori \\
\hline \multirow{3}{*}{ SMP Negeri 3 } & A & 28 & 2,8 & Cukup baik \\
Kota Bima & B & 25 & 2,5 & Kurang baik \\
& C & 25 & 2,5 & Kurang baik \\
& D & 24 & 2,4 & Kurang baik \\
& E & 16 & 1,6 & Sangat kurang baik \\
\hline
\end{tabular}

Berdasarkan hasil observasi terhadap penyusunan dan pelaksanaan PTK yang dilakukan guru di atas dapat di lihat bahwa kategori yang diperoleh ke empat guru tersebut belum mencapai standar minimal keberhasilan dalam penelitian ini yaitu $3.34 \leq \mathrm{X}<4$ dengan kategori baik. Dengan demikian, perlu dilakukan perbaikan-perbaikan pada siklus II.

Berdasarkan hasil penelitian yang diperoleh melalui bimbingan individual terlihat bahwa tindakan tersebut dapat mengoptimalkan kemampuan guru matematika SMP Negeri 3 Kota Bima dalam melaksanakan PTK. Hal ini ditunjukkan dengan meningkatnya kemampuan guru matematika dari siklus I ke siklus II, hasilnya dapat dilihat pada tabel berikut:

Tabel 4. Hasil Tindakan Siklus I dan Siklus II

\begin{tabular}{ccccc}
\hline Nama Sekolah & Nama Guru & $\begin{array}{c}\text { Skor } \\
\text { total }\end{array}$ & $\begin{array}{c}\text { Skor } \\
\text { rata-rata }\end{array}$ & Kategori \\
\hline \multirow{2}{*}{ Siklus I } & & \\
SMP Negeri 3 & A & 28 & 2,8 & Cukup baik \\
Kota Bima & B & 25 & 2,5 & Kurang baik \\
& C & 25 & 2,5 & Kurang baik \\
& D & 24 & 2,4 & Kurang baik \\
& E & 16 & 1,6 & Sangat kurang \\
\hline
\end{tabular}




\begin{tabular}{|c|c|c|c|c|}
\hline & & & & baik \\
\hline \multicolumn{2}{|c|}{ Rata - Rata } & 118 & 2,36 & Cukup baik \\
\hline Nama Sekolah & Nama Guru & $\begin{array}{l}\text { Skor } \\
\text { total }\end{array}$ & $\begin{array}{c}\text { Skor } \\
\text { rata-rata }\end{array}$ & Kategori \\
\hline \multicolumn{5}{|c|}{ Siklus II } \\
\hline & $\mathrm{A}$ & 35 & 3,5 & Baik \\
\hline SMP Negeri 7 & B & 34 & 3,4 & Baik \\
\hline \multirow[t]{3}{*}{ Kota Bima } & $\mathrm{C}$ & 33 & 3,3 & Baik \\
\hline & $\mathrm{D}$ & 34 & 3,4 & Baik \\
\hline & $\mathrm{E}$ & 33 & 3,3 & Baik \\
\hline \multicolumn{2}{|c|}{ Rata - Rata } & 169 & 3,38 & Baik \\
\hline
\end{tabular}

Dari tabel 4 di atas dapat diketahui bahwa adanya peningkatan kemampuan guru matematika dari siklus I 2,36 dengan kategori cukup baik menjadi 3,38 dengan kategori baik pada siklus II, peningkatan ini terjadi karena adanya kerjasama yang baik antara peneliti sebagai tutor dalam bimbingan individual dan guru, peneliti sebagai tutor menjelaskan mengenai konsep dan langkah-langkah melaksanakan PTK, peneliti dan guru bertukar pendapat dan berdiskusi, selain itu adanya kemauan guru dalam menyusun dan melaksanakan PTK. Pelaksanaan penelitian tindakan kelas di kelas masing-masing guru diharapkan dapat meningkatkan mutu guru, memperbaiki proses belajar mengajarnya serta meningkatkan hasil belajar siswa.

Berdasarkan uraian di atas, dapat dikatakan bahwa bimbingan individual dapat mengoptimalkan kemampuan guru matematika dalam menyusun dan melaksanakan penelitian tindakan kelas (PTK).

\section{KESIMPULAN}

Berdasarkan hasil penelitian tindakan sekolah yang telah dilaksanakan, dapat disimpulkan bahwa melalui bimbingan individual dapat mengoptimalkan kemampuan guru matematika SMP Negeri 3 Kota Bima dalam menyusun dan melaksanakan PTK. peningkatan ini terjadi karena adanya kerjasama yang baik antara peneliti sebagai tutor dalam bimbingan individual dan guru, peneliti sebagai tutor menjelaskan mengenai konsep dan langkah-langkah 
melaksanakan PTK, peneliti dan guru bertukar pendapat dan berdiskusi, selain itu adanya kemauan guru dalam menyusun dan melaksanakan PTK. Pelaksanaan penelitian tindakan kelas di kelas masing-masing guru diharapkan dapat meningkatkan mutu guru, memperbaiki proses belajar mengajarnya serta meningkatkan hasil belajar siswa.

Peningkatan kemampuan guru dalam melaksanakan penelitian tindakan kelas ini terlihat dengan meningkatnya hasil kinerja dari siklus I sebesar 2,36 dengan kategori cukup baik menjadi 3,38 dengan kategori baik pada siklus II.

\section{REKOMENDASI}

1. Kepada kepala sekolah, agar melakukan bimbingan secara intensif kepada para guru, sehingga guru lebih termotivasi untuk meningkatkan mutu mengajarnya sehingga dapat meningkatkan hasil pembelajaran.

2. Kepada para guru, agar lebih aktif bertanya kepada para pengawas dan kepala sekolah terkait dengan upaya peningkatan mutu mengajar dan juga diharapkan guru melaksanakan penelitian tindakan kelas dengan mencari alternatif pemecahan masalah yang inovatif, dengan memusatkan pembelajaran pada siswa dan merangsang siswa berpikir sehingga menarik perhatian siswa untuk belajar dan mencari tahu. Mengubah cara mengajar guru, dari guru sebagai sumber belajar menjadi sebagai fasilitator dan motivator.

3. Kepada peneliti lanjutan yang ingin melakukan penelitian serupa dapat mencobakan pada tempat dan materi yang berbeda. Bagi calon peneliti yang ingin menerapkan pembelajaran kooperatif ini dalam penelitiannya, maka harus meluangkan waktu khusus untuk menjelaskan metode tersebut kepada siswa dan juga mengenalkan siswa dengan tugastugas, tujuan dan struktur penghargaan.

\section{UCAPAN TERIMAKASIH}

Penulis menyadari bahwa tanpa bimbingan dan bantuan berbagai pihak tesis ini tidak akan terwujud. Oleh karena itu, penulis mengucapkan banyak terimakasih dan penghargaan setinggi-tingginya kepada:

1. Bapak Dr. Amran Amir, M.Pd selaku Ketua STKIP Bima Atas Sumbangsi dananya Sehingga Penelitian ini dapat Terselesaikan sesuai waktunya

2. Seluruh Staff Dosen di Program studi pendidikan matematika STKIP Bima, yang telah mendidik dan membimbing / menuntun penulis selama melaksanakan Penelitian 
3. Semua sahabat yang telah banyak memberikan masukan dan motivasi. Mudah-mudahan semua do'a, perhatian, bantuan, dan dorongan yang telah diberikan mendapat balasan dari Allah SWT. Amin.

\section{DAFTAR PUSTAKA}

Aswati, S. (2015). Upaya Meningkatkan Kemampuan Guru IPS Dalam Melaksanakan Penelitian Tindakan Kelas Melalui Bimbingan Individual di Sekolah Binaan SMP Negeri 7 Kota Bima. CISOC: Pengembangan Sosial \& Kemampuan Vocational. Vol. 3 No. 1 (2016)

Jatmiko, B. (2014). Penelitian Tindakan Kelas (PTK). Disampaikan Dalam Brainstorming Penelitian Tindakan Kelas di STMIK STIKOM Surabaya Pada 21 Januari 2014. 